\title{
Gamma Radiation-induced Impairment of Hippocampal Neurogenesis, Comparison of Single and Fractionated Dose Regimens
}

\author{
Deterioro de la Neurogénesis en el Hipocampo Inducida por Radiación Gamma, \\ Comparación de los Regímenes de Dosis Única y Fraccionada
}

"Khoshbin khoshnazar, A. R.; ${ }^{* *}$ Jahanshahi, M. \& ${ }^{* * * *}$ Azami, N. S.

KHOSHBIN KHOSHNAZAR, A. R.; JAHANSHAHI, M. \& AZAMI, N. S. Gamma radiation-induced impairment of hippocampal neurogenesis, comparison of single and fractionated dose regimens. Int. J. Morphol., 30(1):145-149, 2012.

SUMMARY: Radiation therapy of the brain is associated with many consequences, including cognitive disorders. Pathogenesis of radiation induced cognitive disorder is not clear, but reduction of neurogenesis in hippocampus may be an underlying reason. 24 adult male rats entered to study. Radiation absorbed dose to midbrain was $10 \mathrm{~Gy}$, delivered by routine cobalt radiotherapy machine which its output was measured $115.24 \mathrm{cGy} / \mathrm{min}$. The rats were divided in four groups of sixes, including groups of control, single fraction $10 \mathrm{~Gy}$, fractionated $10 \mathrm{~Gy}$ and finally anaesthesia sham group. Number of pyramidal nerve cells was counted in two regions of hippocampus formation (CA1 and CA3). The radiation could reduce the number of cells in two regions of hippocampus significantly ( $\mathrm{p}=0.000)$. It seems fractionated $10 \mathrm{~Gy}$ irradiation to more efficient than single fraction, while role of anaesthesia drug should be cautiously assessed. Moreover the rate of neurogenesis reduction was determined the same in these regions of hippocampus meaning the same radiosensitivity of cells.

KEY WORDS: Hippocampus; Neurogenesis; Radiation; Fractionation.

\section{INTRODUCTION}

Radiation therapy is the main modality to treat many brain tumors. It shrinks tumors, providing better management of treatment course and finally high quality of life (Halperin et al., 2008). The hippocampus formation is a bilateral structure sandwiched between the cerebral cortex and the thalamus. It belongs to the limbic system. Hippocampus formation consists of three main parts anatomically: hippocampus proper, dentate gyrus and subiculum complex. Hippocampus has a c-shape concaving to midsagital plane of brain.

The entrohinal cortex, the greatest source of hippocampal input and target of hippocampal output, is strongly connected to many other structure of the cerebral cortex (Bliss \& Lomo, 1973).

Within the hippocampus the flow of information is unidirectional with signals propagating through a series of tightly packed cell layers first to the dentate gyrus then to the CA3 layer, then to the CA1 layer, then to the subiculum, then out of the hippocampus to the entrohinal cortex (Amaral \& Lavenex, 2006). Each of these layers also contains complex intrinsic circuits and extensive longitudinal connections.

Cognitive disorders are one of main consequences of radiotherapy which its Pathogenesis has not been yet known (Andres-Mach et al., 2008). Hippocampus is one of two constructions of central nervous system continuing neurogenesis after birth (Bruel-Jungerman et al., 2007). The studies show neurogenesis in the hippocampus is critical to save memory and proper hippocampal function (Madsen $e t$ $a l ., 2003)$. There are so much data claiming importance of neurogenesis as it relates to the hippocampal functions of learning and memory (Kempermann, 2002; Lemaire et al., 2000; Leuner et al., 2006; Prickaerts et al., 2002; Shors et al., 2001; Snyder et al., 2005; Van Praag et al., 1999; Wiskott et al., 2006). So if radiotherapy arrests neurogenesis in hippocampus it may be an underlying reason for cognitive deficits after receiving radiation (Strother et al., 2002).

* Ph. D. Assistant Professor of Medical Physics, Department of Biochemistry and Biophysics, Golestan University of Medical Sciences, Gorgan, Iran.

** Ph. D. Associate Professor of Anatomy, Neuroscience Research Center, Department of Anatomy, Golestan University of Medical Sciences, Gorgan, Iran.

**** Ph. D. Assistant Professor of Physiology, Department of Biology, Gorgan Branch, Islamic Azad University, Gorgan, Iran. 
Achanta et al. (2009) suggested that cognitive deficits may be associated with reduction in hippocampal cell proliferation and survival in animal models. Yang et al. (2010) showed different rate of hippocampal neurogenesis among different radiation qualities. Moreover Mizumatsu et al. (2003) suggest that precursor cell radiation response and altered neurogenesis may play a neither contributory or causative role in radiation-induced cognitive disorder.

According to Fike et al., it can be concluded that neural precursor cells are extremely sensitive to irradiation, undergoing apoptosis after clinically relevant doses that do not produce apparent tissue injury. Finally there are increasingly evidences that microenvironment of precursor cells determines the whole process of neurogenesis and sensitivity of cells (Fike et al., 2007).

\section{MATERIAL AND METHOD}

Animals. Twenty four adult male wistar rats, weighing 200$250 \mathrm{gm}$ were used in the study. The animals had free access to normal laboratory chow and water. Temperature of animal house was kept within $22 \pm 3$ centigrade. The rats were housed separately in groups of sixes.

Irradiation. Cobalt radiotherapy machine, namely phoenix, was used to irradiate rats. Its output was measured 115.28 $\mathrm{cGy} / \mathrm{min}$ at SSD of $80 \mathrm{~cm}$ at build up depth. The field size was set $5 \times 5 \mathrm{~cm}^{2}$ covering whole brain superiorly, while the eyes of animals were shielded by lead blocks. The irradiation time to deliver $10 \mathrm{~Gy}$ for single fraction and $2 \mathrm{~Gy}$ for fractionated radiation was determined respectively 9.92 and $1.98 \mathrm{~min}$.

For fractionated irradiation the animals were given anesthesia drug in five consecutive days just before taking radiation.

Histology. Tissue processing: One week after radiotherapy the rats were decapitated under diethyl ether anesthesia. Brain was removed and then fixed for two weeks in $10 \%$ formaldehyde. Different degrees of alcohol were used for dehydration followed by clarification with xylol. After histological processing, tissue was impregnated and then embedded in paraffin wax.

The $7 \mu \mathrm{m}$ coronal sections were serially gathered from Bregma $-3.30 \mathrm{~mm}$ to $-6.04 \mathrm{~mm}$ of the hippocampal formation. An interval of $20 \mu \mathrm{m}$ was placed between each two consecutive sections. The sections were stained with cresyl violet in accordance with routine laboratory procedures.
A photograph of each section was captured using an Olympus BX 51 microscope and a DP 12 digital camera under a magnification of $1000^{\prime}$. An area of $3600 \mu \mathrm{m}^{2}$ was selected in all sections. To measure the area density of the pyramidal cells, the images were transferred to the computer. Using OLYSIA Autobioreport software, Olympus Co., the appropriate grids were superimposed on the pictures and the cells were counted manually. To perform an unbiased measurement, the individual was double-blinded and only the cells with significant characteristics were counted. Fig.1 shows neurons stained by cresyl violet dye in CA3 regions of hippocampus.

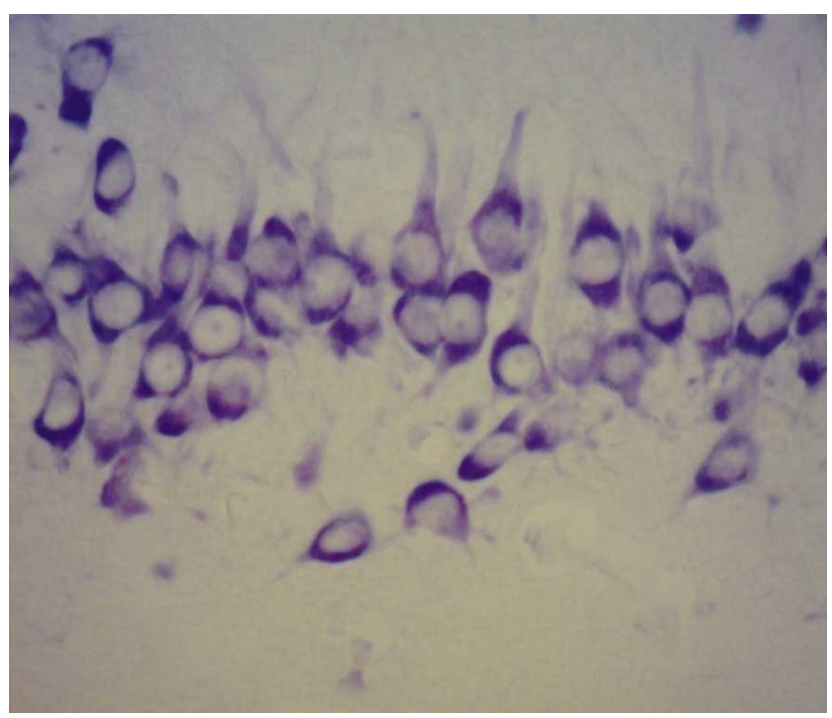

Fig. 1. Neurons in CA3 region of hippocampus X40.

Statistical analysis. All the data were entered into and analyzed by SPSS 11.5 Software. The data was expressed as mean $\pm \mathrm{SD}$. The statistical analysis was performed using one and two way analysis of variance (ANOVA). Post-hoc comparison of means was carried out with the Tukey test for multiple comparisons, when appropriate.

The level of statistical significance was set at $\mathrm{P}<0.05$. Calculations were carried out using the SPSS statistical package.

\section{RESULTS}

Table I shows results of Neurons counts performed in CA1 and CA3 of hippocampus for four groups including control, single fraction $10 \mathrm{~Gy}$, fractionated $10 \mathrm{~Gy}$ and anesthesia sham. Table II shows multiple comparisons carried out between control group and other groups using 
Tukey test. As the table shows 10 Gy single fraction dose and also fractionated could reduce number of pyramidal cells in $\mathrm{CA} 1$ and $\mathrm{CA} 3$ regions of hippocampus $(\mathrm{p}=0.000)$.

The data demonstrate no difference between reductions of neurogenesis among above mentioned regions meaning same radio sensitivity.

As the rats in fractionated 10 Gy group were given anesthesia in five consecutive days, to rule out the effect of anesthesia drug, a sham anesthesia group of rats were anesthetized in the same fashion but did not receive radiation. As the Table II shows anesthesia drug could also significantly reduce neurogenesis, lowered neurogenesis in fractionated group may be a synergic result of radiation and drug effects. With this condition comparing single fraction and fractionated groups must be made cautiously. Table III also compares Single 10 Gy fraction and other groups.

As there is no significant difference between single faction and fractionated regimen in CA1 and CA3 respectively ( $\mathrm{p}=0.998$ and $\mathrm{p}=1.000$ ). According to our result difference of cell counts between two regimens of irradiation has not been observed significantly in CA1 and CA 3 regions respectively.

Table I. Cell counts result in four groups including control, single fraction $10 \mathrm{~Gy}$, fractionated $10 \mathrm{~Gy}$ and anesthesia sham.

\begin{tabular}{llcc}
\hline Group & & CA1 & CA3 \\
\hline Control & Mean & 22.92 & 19.30 \\
& Std. Deviation & 4.009 & 3.164 \\
Single 10Gy & Mean & 14.95 & 13.15 \\
& Std. Deviation & 2.660 & 2.568 \\
Fractionated 5_2 Gy & Mean & 14.55 & 13.12 \\
& Std. Deviation & 2.099 & 2.377 \\
Anesthesia Sham & Mean & 16.10 & 14.17 \\
& Std. Deviation & 2.827 & 2.601 \\
\hline
\end{tabular}

Table II. Multiple comparisons carried out between control group and other groups using Tukey

\begin{tabular}{llccc}
\hline test. & Group & Mean Difference & Std.error & Significance \\
\hline CA1 (control group) & Single fraction & 7.975 & 0.727 & 0.000 \\
& fractionated & 8.375 & 0.727 & 0.000 \\
& Anesthesia sham & 6.825 & 0.727 & 0.000 \\
CA3 (control group) & Single fraction & 6.150 & 0.650 & 0.000 \\
& fractionated & 6.175 & 0.650 & 0.000 \\
& Anesthesia sham & 5.125 & 0.650 & 0.000 \\
\hline
\end{tabular}

Table III. Multiple comparisons carried out between Single fraction $10 \mathrm{GY}$ group and other groups using Tukey test.

\begin{tabular}{llccc}
\hline Region & Group & Mean & Std.error & Significance \\
\hline CA1 (Single fraction group) & Control & -0.975 & 0.727 & 0.000 \\
& fractionated & 0.400 & 0.727 & 0.998 \\
& Anesthesia sham & -.1 .150 & 0.727 & 0.694 \\
CA3 (Single fraction group) & Control & -6.150 & 0.650 & 0.000 \\
& fractionated & 0.025 & 0.650 & 1.000 \\
& Anesthesia sham & -1.025 & 0.650 & 0.697 \\
\hline
\end{tabular}

\section{DISCUSSION}

Neural stem cells which are self renewal cells that generate neurons, astrocytes and oligodendrocytes, reside in adult hippocampus and via production new dentate gyrus granul neurons (Gage et al., 1998; Palmer et al., 1997) in all vertebrae including humans (Eriksson et al., 1998). They have significant importance to baseline hippocampal neurogenesis supporting cognitive functions in adults (Shors et al. ). 
In this study we showed that adult neurogenesis can be reduced by 10 Gy cobalt radiation in both single and fractionated mode, the result perceived by some authors (Madsen et al.). Our new result is a comparison between two regions of CA1 and CA3 belonging to hippocampus which shows no difference in radiosensitivity. The number of newly born neurons in adult rat hippocampus has been controversial, however, thought to be less than of previously existing granular neurons (Cameron \& Mckay, 2001).

Shors et al. showed animals with reduced neurogenesis have impaired hippocampal-dependent function. The decrease in neurogenesis is the result of a reduction of stem cell pool due to apoptosis. Monje and Palmer showed that $10 \mathrm{~Gy}$ radiations, which is comparable with therapy dose can't completely arrest neurogenesis (Monje \& Palmer, 2003). Inflammatory response and changes of microvasculator of neurons are other cause of neurogenesis impairment (Monje et al., 2003).

More effectiveness of fractionated $10 \mathrm{~Gy}$ dose than single fraction one may be due to addition of effect of anesthesia drug to radiation. Anesthesia drug effect to reduce neurogenesis advised to be assessed by other researchers.

Rola et al. (2004) showed that shortly after irradiation a huge reduction of dividing cells and immature neurons will be taken place which persists for some months after radiation, so reduction of neurons one week after irradiation in our experiment can be acceptable. Although stochastic nature of radiation dictates that some fraction of neurons is alive after radiation, even at high dose of radiation.

According to similar works performed recently (Mizumatsu et al. ; Parent et al., 1998; Snyder et al., 2009; Winocur et al., 2006) it can be concluded that survival and differentiation of newly born cells into mature neurons is highly affected by irradiation. The hippocampus and olfactory bulb are two structures of central nervous system continuing neurogenesis after birth. Thus perfect operation of these structures should be affected by neurogenesis (BruelJungerman et al. ).

Madsen et al. showed that neurogenesis in hippocampus is important for memory and proper hippocampal functionality. Monje \& Palmer indicate that neurogenesis reduction is resulted from radiation-induced apoptosis of the neurons. Exploring the exact reason of apoptosis is critical as it can practical to inhibit apoptosis and reverse the effects.

We showed that fractionated 10 Gy dose can reduce number of cells in CA1 and CA3 of hippocampus. Using of anesthesia drug for each consecutive fraction and moreover reduction of neurogenesis in anesthesia sham group may make us ambiguous with regard to definite results. Although Madsen et al. showed block of neurogenesis after fractionated $10 \mathrm{~Gy}$ of radiation (Madsen et al. ). Of course no publisheded data regarding anesthesia drug and neurogenesis and also no work on $\mathrm{CA} 1$ and $\mathrm{CA} 3$ regions encourage new studies.

ACKNOWLEDGEMENTS. The authors would like to thank staff of Radiotherapy section of 5 Azar Hospital of Gorgan. We are also thankful for financial support of research affairs of Golestan University of Medical Sciences.

KHOSHBIN KHOSHNAZAR, A. R.; JAHANSHAHI, M. \& AZAMI, N. S. Deterioro de la neurogénesis en el hipocampo inducida por radiación gamma, comparación de los regímenes de dosis única y fraccionada. Int. J. Morphol., 30(1):1145-149, 2012.

RESUMEN: La terapia de radiación cerebral está asociada con muchas consecuencias, incluyendo los trastornos cognitivos. La patogénesis del trastorno cognitivo inducido por la radiación no está claro, pero la reducción de la neurogénesis en el hipocampo puede ser una razón subyacente. Fueron etudiadas 24 ratas macho adultas. La dosis de radiación absorbida en el mesencéfalo fue de 10 Gy, proveniente de una máquina de radioterapia de cobalto con una salida de $115,24 \mathrm{cGy} / \mathrm{min}$. Las ratas fueron divididas en cuatro grupos de seis ratas cada uno, incluyendo un grupo control, fracción única de 10 Gy, fraccionada de 10 Gy y finalmente el grupo de anestesia simulado. El número de células nerviosas piramidales se contó en dos regiones de la formación del hipocampo (CA1 y CA3). La radiación podría reducir significativamente $(\mathrm{p}=0,000)$ el número de células en dos regiones del hipocampo. Al parecer, la radiacioón fraccionada de 10 Gy es más eficiente que la fracción única, mientras que el rol de la anestesia debe ser cuidadosamente evaluado. Por otra parte la tasa de reducción de la neurogénesis fue observada en las mismas regiones del hipocampo es decir, con la misma radiosensibilidad de las células.

PALABRAS CLAVE: Hipocampo; Neurogénesis; Radiación; Fraccionamiento.

\section{REFERENCES}

Achanta, P.; Fuss, M. \& Martinez, Jr. J. L. Ionizing Radiation Impairs the Formation of Trace Fear Memories and Reduces Hippocampal Neurogenesis. Behav. Neurosci., 123:1036-45, 2009.

Amaral, D. \& Lavenex, P. Hippocampal Neuroanatomy. New York, Oxford University Press, 2006.

Andres-Mach, M.; Rola, R. \& Fike, J. Radiation effects on neural precursor cells in the dentate gyrus. Cell Tissue Res., 331:25162, 2008.

Bliss, T. V. \& Lomo, T. Long-lasting potentiation of synaptic transmission in the dentate area of the anaesthetized rabbit following stimulation of the perforant path. J. Physiol., 232:33156, 1973. 
Bruel-Jungerman, E.; Rampon, C. \& Laroche, S. Adult hippocampal neurogenesis, synaptic plasticity and memory: facts and hypotheses. Rev. Neurosci., 18:93-114, 2007.

Cameron, H. A. \& Mckay, R. D. G. Adult neurogenesis produces a large pool of new granule cells in the dentate gyrus. J. Comp. Neurol., 435:406-17, 2001.

Eriksson, P. S.; Perfilieva, E.; Björk-Eriksson, T.; Alborn, A. M.; Nordborg, C.; Peterson, D. A. \& Gage, F. H. Neurogenesis in the adult human hippocampus. Nat. Med., 4:1313-7, 1998.

Fike, J. R.; Rola, R. \& Limoli, C. L. Radiation response of neural precursor cells. Neurosurg. Clin. N. Am., 18:115-27, 2007.

Gage, F.; Kempermann, G.; Palmer, T.; Peterson, D. \& Ray, J. Multipotent progenitor cells in the adult dentate gyrus. $J$. Neurobiol., 36:249-66, 1998.

Halperin, E. C.; Perez, C. A. \& Brady, L. W. Perez and Brady's principles and practice of radiation oncology. Philadelphia, Lippincott Williams \& Wilkins, 2008.

Kempermann, G. Why new neurons? Possible functions for adult hippocampal neurogenesis. J. Neurosci., 22:635-8, 2002.

Lemaire, V.; Koehl, M.; Le Moal, M. \& Abrous, D. Prenatal stress produces learning deficits associated with an inhibition of neurogenesis in the hippocampus. Proc. Natl. Acad. Sci. U S A, 97:11032-7, 2000 .

Leuner, B.; Gould, E. \& Shors, T. J. Is there a link between adult neurogenesis and learning? Hippocampus, 16:216-24, 2006.

Madsen, T.; Kristjansen, P.; Bolwig, T. \& Wörtwein, G. Arrested neuronal proliferation and impaired hippocampal function following fractionated brain irradiation in the adult rat. Neuroscience, 119:635-42, 2003.

Mizumatsu, S.; Monje, M.; Morhardt, D.; Rola, R.; Palmer, T. \& Fike, J. Extreme sensitivity of adult neurogenesis to low doses of Xirradiation. Cancer Res., 63:4021-7, 2003.

Monje, M. L. \& Palmer, T. Radiation injury and neurogenesis. Curr. Opin. Neurol., 16:129-34, 2003.

Monje, M. L.; Toda, H. \& Palmer, T. D. Inflammatory Blockade Restores Adult Hippocampal Neurogenesis. Science, 302:17605, 2003.

Palmer, T. D.; Takahashi, J. \& Gage, F. H. The Adult Rat Hippocampus Contains Primordial Neural Stem Cells* 1. Mol. Cell. Neurosci., 8:389-404, 1997

Parent, J. M.; Janumpalli, S.; McNamara, J. O. \& Lowenstein, D. H. Increased dentate granule cell neurogenesis following amygdala kindling in the adult rat. Neurosci. Lett., 247:9-12, 1998.

Prickaerts, J.; van Staveren, W.; Sik, A.; Markerink-van Ittersum, M.;
Niewöhner, U.; van der Staay, F. J.; Blokland, A. \& de Vente, J. Effects of two selective phosphodiesterase type 5 inhibitors, sildenafil and vardenafil, on object recognition memory and hippocampal cyclic GMP levels in the rat. Neuroscience, 113:351$61,2002$.

Rola, R.; Raber, J.; Rizk, A.; Otsuka, S.; VandenBerg, S. R.; Morhardt, D. R. \& Fike, J. R. Radiation-induced impairment of hippocampal neurogenesis is associated with cognitive deficits in young mice. Exp. Neurol., 188:316-30, 2004.

Shors, T. J.; Miesegaes, G.; Beylin, A.; Zhao, M.; Rydel, T. \& Gould, E. Neurogenesis in the adult is involved in the formation of trace memories. Nature, 410:372-6, 2001.

Snyder, J.; Hong, N.; McDonald, R. \& Wojtowicz, J. A role for adult neurogenesis in spatial long-term memory. Neuroscience, 130:843-52, 2005.

Snyder, J. S.; Choe, J. S.; Clifford, M. A.; Jeurling, S. I.; Hurley, P.; Brown, A.; Kamhi, J. F. \& Cameron, H. A. Adult-born hippocampal neurons are more numerous, faster maturing, and more involved in behavior in rats than in mice. J. Neurosci., 29:14484-95, 2009.

Strother, D.; Pollack, I.; Fisher, P.; Hunter, J.; Woo, S. \& Pomeroy, S. Tumors of the central nervous system. In: Pizzo, P. A. \& Poplack, D. G. (Eds). Principles and Practice of Pediatric Oncology. Philadelphia, Lippincott Williams and Wilkins, 2002.

van Praag, H.; Christie, B. R.; Sejnowski, T. J. \& Gage, F. H. Running enhances neurogenesis, learning, and long-term potentiation in mice. Proc. Natl. Acad. Sci. U S A, 96:13427-31, 1999.

Winocur, G.; Wojtowicz, J. M.; Sekeres, M.; Snyder, J. S. \& Wang, S. Inhibition of neurogenesis interferes with hippocampusdependent memory function. Hippocampus, 16:296-304, 2006.

Wiskott, L.; Rasch, M. J. \& Kempermann, G. A functional hypothesis for adult hippocampal neurogenesis: avoidance of catastrophic interference in the dentate gyrus. Hippocampus, 16:329-43, 2006.

Yang, M.; Kim, J. S.; Song, M. S.; Kim, J. C.; Shin, T.; Lee, S. S.; Kim, S. H. \& Moon, C. Dose-response and relative biological effectiveness of fast neutrons: Induction of apoptosis and inhibition of neurogenesis in the hippocampus of adult mice. Int. J. Radiat. Biol., 86:476-85, 2010.

\section{Correspondence to:}

Dr. Mehrdad Jahanshahi

Department of Anatomy

Neuroscience Research Center, Faculty of Medicine

Golestan University of Medical Sciences

Km 4 Gorgan-Sari road (Shastcola)

Gorgan, Postal Code: 4934174515

IRAN

Email: mejahanshahi@yahoo.com

Received: 26-08-2011

Accepted: 17-10-2011 